\begin{tabular}{|l} 
Sosial Politik Humaniora \\
http://journal.umpo.ac.id/index.php/aristo/ aristo@umpo.ac.id
\end{tabular}

\title{
Forestry and agriculture policy governance regarding water contestation in State Production Forest (Case of Margo and Ngiyom spring water in Begal forest, Ngawi Regency)
}

\author{
Anna Istyaningrum \\ MPKD, Faculty of Engineering, Universitas Gadjah Mada, Indonesia \\ istyaningrumanna@yahoo.co.id
}

\begin{abstract}
Water related problem usually involving many stakeholder with different interest, attitude, power scale and level, which make it complex as well as water contestation problem in Begal State production forest in Ngawi Regency which involving different level government agency and its community base institution. Teak production forest and rice agriculture area usually located nearby especially in Ngawi regency with $40 \%$ agriculture area and $32 \%$ forest area, which make high occurrence of water related problem. This research purpose is to identify and analyze the root of water contestation among involved stakeholder in Ngiyom and Margo spring water utilization and its leading factors. In depth interview was done to all involved stakeholder in February 2017 to obtain the data about the water contestation problem in this area. Although changes in water and forest land utilization are causing water contestation problem but understanding root of water problem in this research from agriculture and forestry policy are important to make a sustainable solution. Forestry and agriculture governance are use to understand the relation among stakeholder toward water contestation in this area. Social ecological system framework that captures the relation among resource users and governance to resources utilization is useful to get the whole picture of water contestation problem in this area. Government policy on rice agriculture and forestry sector was indirectly affecting the water contestation problem in this area. Combined with in field governance, government policy effect were causing social and economic gap among water resources user in this area.
\end{abstract}

Keyword: Irrigation Water Contestation, Forestry Governance, Rice Agriculture Governance

\begin{tabular}{|ll|}
\hline Submite & $:$ 20 Desember 2017 \\
Review & $:$ 15 Januari 2018 \\
Accepted & $:$ 30 Juni 2018 \\
Surel Corespondensi & $:$ hayat.150318@gmail.com \\
\hline
\end{tabular}

\section{Introduction}

Water is important resources in human livelihood and has no administrative boundary which create mismatch problem of resource and institutional boundaries. Resource boundaries rarely match institutional boundaries such as water related problem and face several kinds of scale mismatch institutions which do not "fit" to resource or ecosystem boundaries for a number of ecological reasons, including the complexity and dynamics of ecosystems. Interconnected surface water and groundwater in quantity and quality has to consider in viewing the water utilization related problem which usually involve many institution with different interest and different level governance institution as happened in Margo and Ngiyom spring water. 


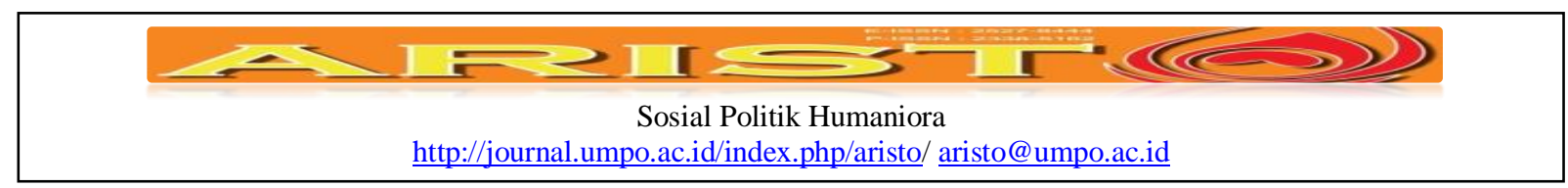

Land utilization of an area also describing it main activities. The potential land utilization of Ngawi regency is on agriculture and forestry, from total area of $129,598 \mathrm{Ha}(2.75 \%$ of the total area of East Java Province) about 39 percent (50,476 Ha) is utilize as paddy fields and $32 \%$ (41,903 Ha) utilize as forest which $4,470 \mathrm{Ha}$ of it is community forestry and state forest 37,433 ha (Ngawi statistic data, 2015). Agriculture and forestry as main land utilization in this area make the water contestation problem in this area often appear and quite similar in term of motive. If in good condition, Ngawi forest area is enough to maintain the water recharge rate in a good condition. But, in 1997's monetary crisis and political chaos has destroy java forest, mass illegal logging that happened at that time was deforest at least $21 \%$ of Java forests during the period $1997-2000$ as well as state production forest in Ngawi regency.

State teak production forest in Ngawi regency was established in Dutch colonial and now governed by Perhutani (Indonesian Forest enterprises) which under State Enterprises Ministry authority. Long history of teak production forest governance is shaping the relation between forest authority and villager near the forest area in seeing forest and its resources. After Indonesia independence, the state forest authority was under forestry ministry and later delegated to Indonesian Forest Enterprises. Through Indonesia Consultative assembly decree No. 11/MPRS/1960, Indonesian Forest Enterprises functioned to financially support national development project. Over harvest timber was done to cope with government target of non oil revenue growth for $4 \%$ per year (Peluso, 2009).

In $8^{\text {th }}$ world forestry congress held in Jakarta 1978, the term of Social forestry was start to take into account by Indonesian forestry policy as mentioned by vice president Adam Malik in his speech. Although already politically stated, but social forestry was not well implemented in Indonesia since this program regulated without assistance and willingness to empower local people. social conflict of local people and Forest authority resulted in mass illegal logging that deforest at least 23\% (558,749 ha) of Java forests during the period 1998 - 2000 (Santoso, 2004).

On the other hands, from agriculture governance, previous centralized agriculture development is affecting nowadays rice agriculture activities in this area. Green revolution is the movement of significant increasing crop production from modern agriculture innovation in third world country since 1960's. "High yield varieties/ HYV" terminology is used to mislead monoculture agriculture benefit which is high productivity from new seed variety itself (Shiva, 1993). 


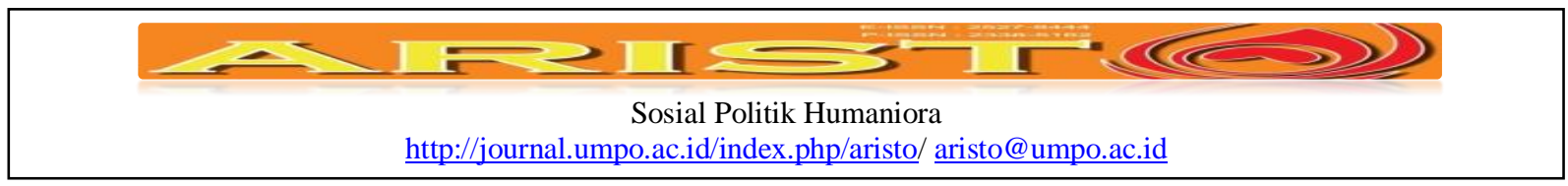

The Green revolution packages introduced in Indonesia through rice self sufficiency program under the Suharto government in 1961. This program not only aimed to fulfill national food security need but also maintain political and economic stability. Major factors that cause high yield increase are high utilization of fertilizer and improved irrigation network. Much larger government budget was allocated to rehabilitation and expansion irrigation infrastructure which mostly funded by foreign aid and soft loan from World Bank (Manning, 1987).

East Java role in supporting national food security proven by it contribution to national rice production which always positioned in top 3 of highest rice producer area in Indonesia since 1993- 2012 (Indonesia statistic report 2013) and Ngawi regency is including top 5 of rice producer in East Java province. Irrigation water is essential to support the success of rice agriculture in this area. Viewing agriculture and forestry governance in this area would help in capturing the whole water contestation problem in the state production forest in this research area.

Begal forest is located 3 sub district; Ngrambe, Widodaren and Kedunggalar sub district. Ngiyom and Margo spring water are two spring water that located inside of Begal forest (state teak production forest) which previously utilized by local government irrigation agency to irrigate more than 1.400 hectares rice field in nearby area but after 2000, the land utilization changes in forest area was stopping the water supply to irrigation rice field area as described below;
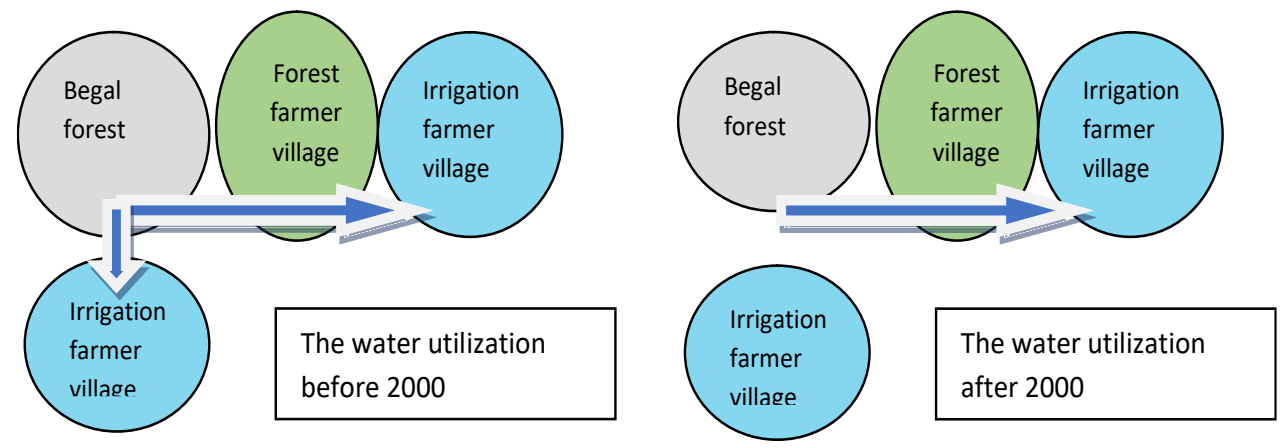

Figure 1. the water utilization changes in Margo and Ngiyom Spring water

The water contestation problem is complex because involving multi level government institutions and its community empowerment organization which are; state production forest governance (Indonesian Forest Enterprises) under Ministry of State own Enterprises, Community 


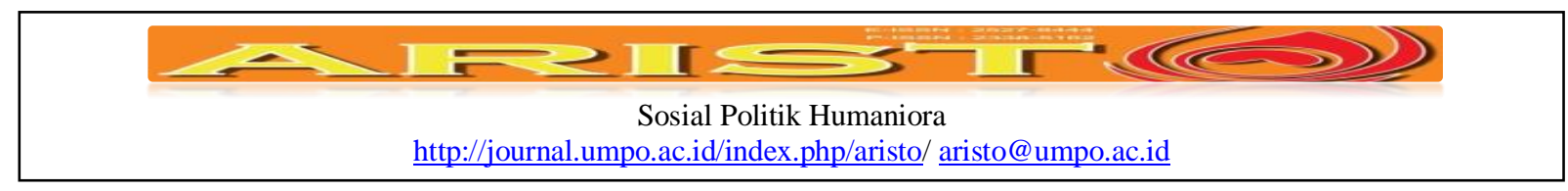

based forestry in Sekarputih Village, local government irrigation agency for Agriculture governance and water user association in Begal village. Since there is not any improvement in spring buffer area vegetation, some local people through Kraton Ngiyom non-profit organization try to establish buffer area conservation through series of happening art in 2015. This initiative rooted from traditional local belief on spring and able to gather Indonesian Forest Enterprises, Ngawi Local Government, forest an irrigation farmer to support spring area conservation. although successes in gathering all stake holder on reforesting buffer area but the water contestation problem is still occur and need to be resolved in order preventing further environmental and social risk from water scarcity. Water contestation in forest and rice field area is unique phenomenon that needs to be understanding in order to establish sustainable spring water utilization and reduce water contestation problem in Although happen in local level, but the complexity of the problem as well as the relation among involved stakeholder in this area is the small model of complex regional water problem since there are many villages in Ngawi that borders to state production forest and shared the water resources for agriculture use. Furthermore, un-resolved water contestation problem in this area would lead into other environmental problem.

Well known Hardin (1968) parable about "Tragedy of the common" problem that appear from uncontrolled resources utilization was proposed solution as either government or private party control are the best resources management. But through Elinor Ostrom seminal work (1990), the success story of resources management by local people are used to build Social Ecological System (SES) framework to depict all involved stakeholders interaction regarding resource utilization in broader social (political) and ecological setting. SES framework is used in this research to find the causal of water contestation problem in this area through governance policy and each involved stakeholder interaction. SES framework is a new and dynamic theory, many case studies on resources governance system are enriching the establishment of this theory.

\section{Method}

This research is exploratory case study with a qualitative and quantitative approach to identify the relation among stakeholder and resources governance policy that involved in Margo and Ngiyom spring water and buffer area utilization which contribute to water contestation in this area. the Social Ecological System Framework approach, is used to capture the interaction 


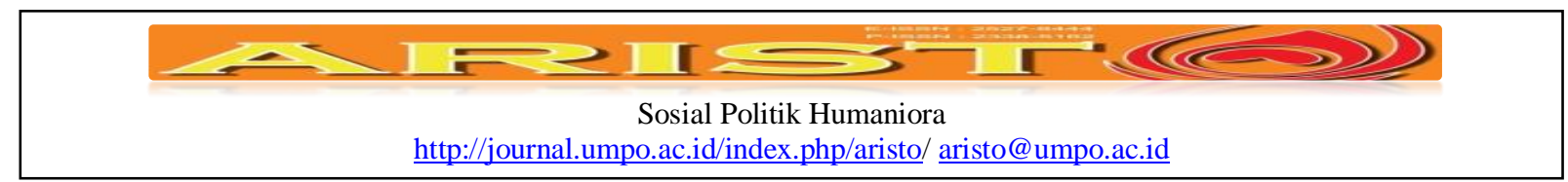

among resource system, governance system and actor as well as social, political setting which resulting water contestation in this area.

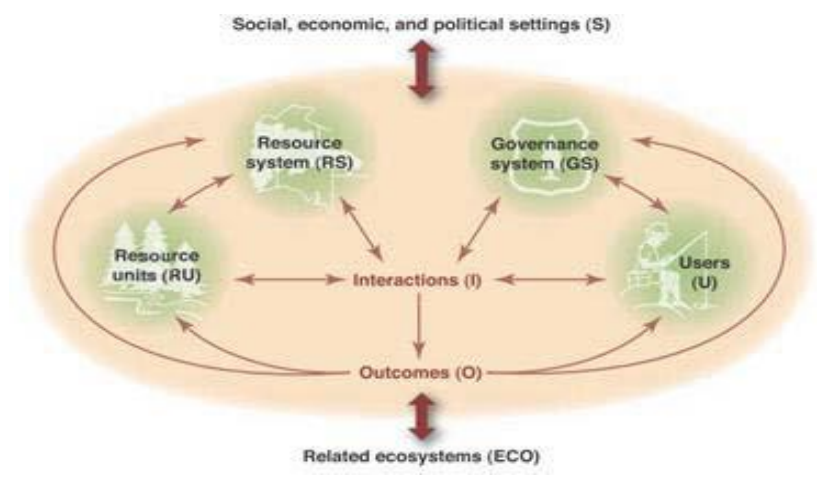

Figure 2. The core system of social ecological system framework (Ostrom, 2009)

Social-ecological system (SES) framework is sub section of social systems in which interdependent relationships among humans are mediated through interactions with biophysical and non-human biological units, its complexity of multi level and multi scale relationship among its component captured by this SES framework (Anderies, 2004). The social-ecological system represents the integration of the social/political and the ecological scales. It emphasizes the view that social and ecological systems are linked, and that the delineation between the two is artificial and arbitrary (Berkes and Folke 1998). Action situation (Interaction and outcomes) of particular resources and it resources user on their livelihood from social and ecological component can be breakdown to smaller situated context or broader aggregates. In depth interview was done to 37 respondents from involved stakeholders in February 2017.

Some stakeholders in this research are grouping into resources governance, users and a local NPO (Non-profit organization) as described in figure3.

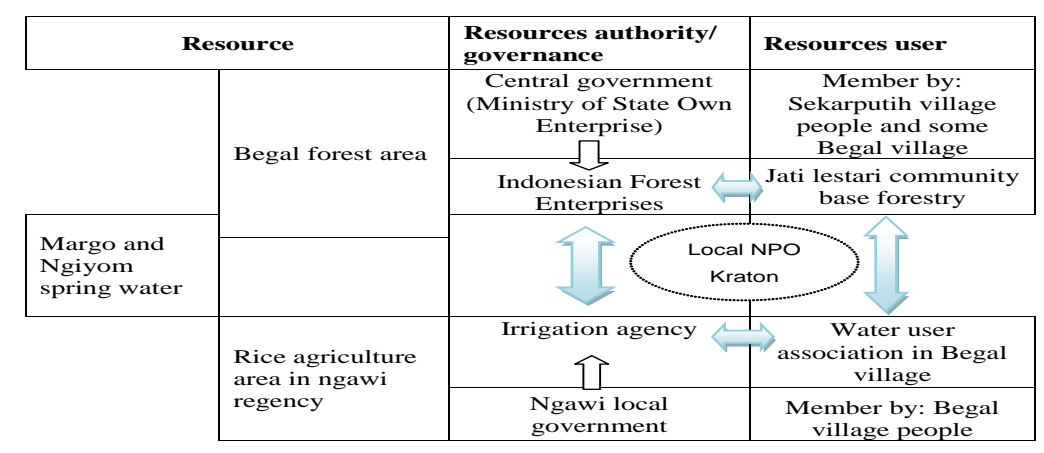

Figure 3 involved stakeholder and their connection 


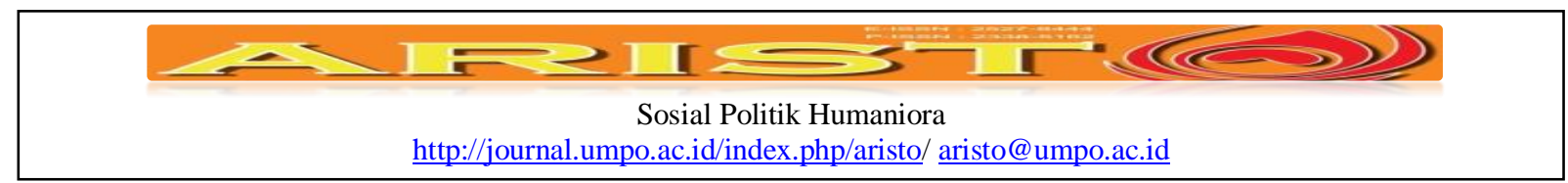

Research workflow of this study is shown in figure 4. This study start with identify the past and recent policy related to agriculture and forestry, current condition of resources system both forest and water resources, resource governance and their relation with resources user group regarding water contestation problem. Stakeholder and data analysis was done respectively.

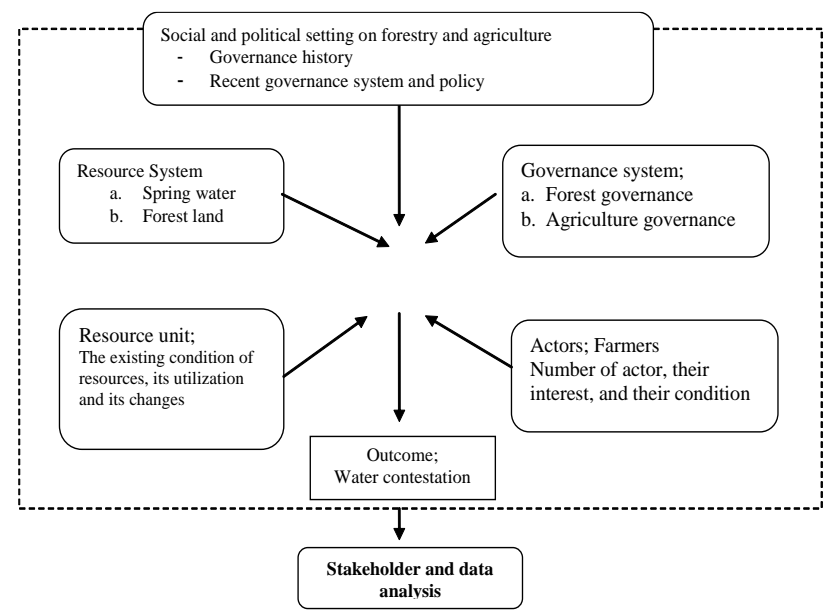

Figure 4. the research framework

\section{Result and Discussion}

Begal forest is a state production forest under Indonesian Forest Enterprises authority with area width $2,737.80$ ha and teak tree ( $\underline{\text { Tectonia }}$ grandis $)$ as the main product. Teak tree is well known as strong log for house making material but it grows very slowly which takes 80 years to harvest fully grown tree. This forest vegetation dominated by $1^{\text {st }}(0-10$ years tree age) and ${ }^{2 n d}$ (10-20 year tree age, each tree age class is ranged 10 years) which means, mass deforestation destroy almost all trees in this area in 1998-2000. The condition of deforested Begal forest area is affecting the spring water condition which reduces its water debit.
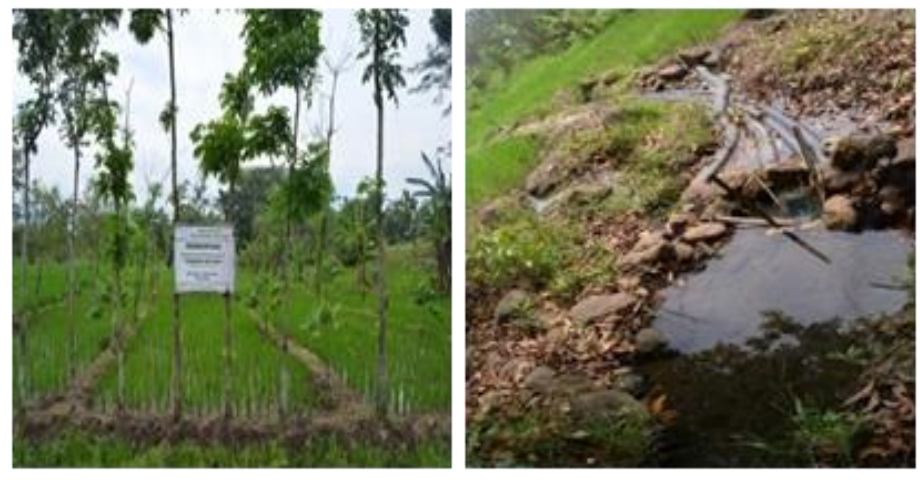

Picture 1. Rice agriculture in spring buffer area (left) and spring water utilization by forest farmers 


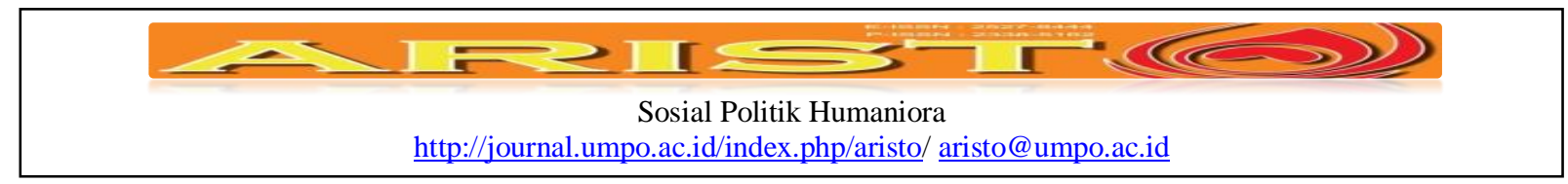

The entire respondent stated that the spring vegetation in spring area was drastically changes after 1998 mass deforestation such as less buffer vegetation, the disappearance of small spring in river side area, decreasing spring water debit into 81/s (from 101/s according to Ngawi Irrigation agency) and converted buffer and river side area into rice field area. Margo and Ngiyom are spring water that located inside Begal forest, which is state production forest under Indonesian Forest Enterprises KPH Ngawi. These two spring water located near one to each other $(500 \mathrm{~m})$, but its utilization is a little bit different. In Margo spring water, water tapping pool was built by Dutch government in late $19^{\text {th }}$ century for recreational and rice field irrigation purposes. Whilst, Ngiyom spring water is remain natural and utilize for daily activities and irrigation use.

Although located inside state production forest, but the water from these two spring was utilize by irrigation agency to irrigate 1,400 ha rice field in this area. There was not any problem before 2000, but when political and monetary crisis hit in 1998, mass deforestation was happen in Begal forest. Along with deforestation effect, changes in forest land utilization, more intensive rice planting cycle and Indonesia decentralization policy has made water contestation conflict is annually happen in this area especially in dry season.

Decentralization policy that regulated in the end 2001 has change the government structure. Delegation of authority from central government as well as managing local natural resources in short time bring some consideration in governing local resources that under other or central authority governance. Eventually, overlapping authority of centralist Indonesian Forest Enterprises (autonomous institution under ministry of state Enterprises) and decentralist irrigation agency under Ngawi local government become a problem afterward. In order to get the picture of existing relationship among stakeholder in this area based on field observation, chart below will be describes each stakeholder interest and its power on authority and influence regarding water contestation problem. 


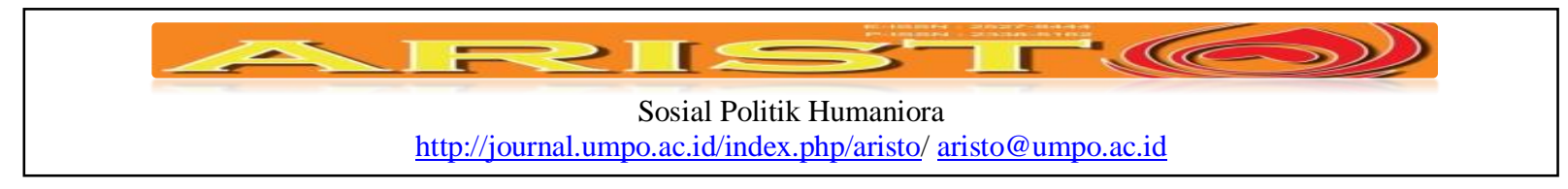

Table 1. Stakeholder analysis regarding water contestation problem

\begin{tabular}{|c|c|c|c|c|c|}
\hline \multirow{2}{*}{$\begin{array}{c}\text { Key } \\
\text { stakeholder }\end{array}$} & \multirow{2}{*}{ Interest } & \multirow{2}{*}{ Attitude } & \multirow{2}{*}{ Condition } & \multicolumn{2}{|c|}{ Power } \\
\hline & & & & Authority & Influence \\
\hline $\begin{array}{l}\text { Indonesian } \\
\text { Forest } \\
\text { Enterprises } \\
\text { (Forest } \\
\text { authority) }\end{array}$ & $\begin{array}{l}\text { Manage } \\
\text { production forest } \\
\text { for timber } \\
\text { production profit }\end{array}$ & $\begin{array}{l}\text { focused on increasing } \\
\text { timber production } \\
\text { after } 1998 \text { mass } \\
\text { deforestation }\end{array}$ & $\begin{array}{l}\text { - According to Government law } \\
\text { no. } 72 / 2010 \text { Indonesian Forest } \\
\text { Enterprises mandates to manage } \\
\text { production forest in java and } \\
\text { Madura Island including } \\
\text { protecting future forest resources, } \\
\text { and conservation. } \\
\text { - Support state company food } \\
\text { security program (GP3K) } \\
\text { - Lose their forest due to 1998- } \\
\text { 2000 mass deforestation }\end{array}$ & Strong & Strong \\
\hline $\begin{array}{c}\text { Forest } \\
\text { farmers }\end{array}$ & $\begin{array}{l}\text { Land to grow } \\
\text { food crops; } \\
\text { livelihood } \\
\text { improvement; } \\
\text { co-ownership of } \\
\text { trees; share in } \\
\text { timber revenues }\end{array}$ & $\begin{array}{l}\text { try to get benefit } \\
\text { from forest } \\
\text { agriculture or even } \\
\text { create rice field in } \\
\text { spring buffer area } \\
\text { and along the } \\
\text { riverside area }\end{array}$ & $\begin{array}{l}\text { - Has obligation to secure } \\
\text { Indonesian Forest Enterprises tree } \\
\text { whilst doing forest agriculture in } \\
\text { allocated area. } \\
\text { - Mostly poor land less farmer } \\
\text { from nearby forest }\end{array}$ & Medium & Low \\
\hline $\begin{array}{c}\text { Irrigation } \\
\text { agency }\end{array}$ & $\begin{array}{l}\text { Water to irrigate } \\
\text { more than } 1,400 \\
\text { hectare rice field }\end{array}$ & $\begin{array}{l}\text { focused on securing } \\
\text { water source } \\
\text { distribution }\end{array}$ & $\begin{array}{l}\text { - According to Law } 37 / 2014 \text { on } \\
\text { water and land conservation, } \\
\text { Local government has obligation } \\
\text { to conserve spring water area. } \\
\text { - Has obligation to regulate ground } \\
\text { water extraction according to } \\
\text { Government law No } 83 / 2008 \text { on } \\
\text { ground water }\end{array}$ & Medium & Strong \\
\hline $\begin{array}{c}\text { Irrigation } \\
\text { farmer }\end{array}$ & $\begin{array}{l}\text { Water for } \\
\text { agriculture }\end{array}$ & $\begin{array}{c}\text { Focused on fulfilling } \\
\text { water need for rice } \\
\text { agriculture } \\
\text { (3times/year)by } \\
\text { surplice from dug well }\end{array}$ & $\begin{array}{l}\text { - mostly land own farmer } \\
\text { - highly depend on rice agriculture } \\
\text { for main income }\end{array}$ & Low & Low \\
\hline $\begin{array}{c}\text { Kraton } \\
\text { Ngiyom }\end{array}$ & $\begin{array}{l}\text { Conserving the } \\
\text { buffer area } \\
\text { through cultural } \\
\text { and art } \\
\text { activity(2015) }\end{array}$ & $\begin{array}{l}\text { Try to establish buffer } \\
\text { protected area, and } \\
\text { improve resource } \\
\text { condition }\end{array}$ & $\begin{array}{l}\text { - Has moral consideration to } \\
\text { improve the water resources and } \\
\text { it nearby area environment } \\
\text { condition }\end{array}$ & Medium & Strong \\
\hline
\end{tabular}

\section{Forest farmers and irrigation farmers condition}
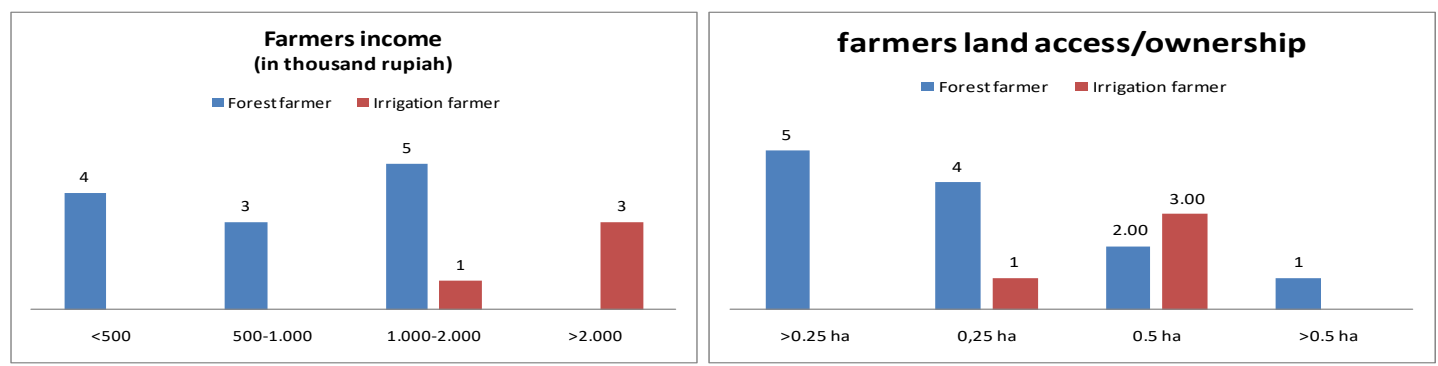

figure 5. Farmer's income (Left) and land access (forest farmer)/ land ownership (irrigation farmers) (Right) 


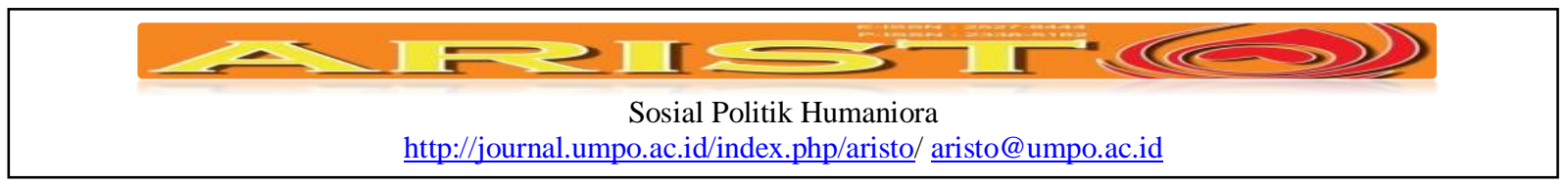

From the graph above, there is income and land ownership gap between irrigation farmer and forest farmer. It was gross income calculation, with high production input cost which cost up to $30 \%$ of gross production (Indonesian Statistic data, 2015), farmer earn less than decent living standard in this area which is 1,334,000 idr. Small agriculture income make farmers have to seek another source of income. According to interview with farmer, usually work as seasonal agriculture labor, trade labor in local market, construction labor or even taking care of other people livestock. For agriculture income is regular income that they can count on once every 6 month for dry agriculture (peanut or maize) and 4 month for rice field agriculture

The loose forest ranger monitoring on forest agriculture is lead forest farmers to prolong the agro forestry time and constrain the main tree growth. Usually agriculture in forest area was done among the teak tree lines for only 1-3 year of teak tree aged and it prolong into 5 year after 2000. After 5 year period, teak tree canopy will constraint the agriculture crop to grow optimally. Since almost all forest area is reforested in almost same time, it means that although the agriculture time already prolonged, but available area for the agriculture will be not continuously available like before mass deforestation. The forest farmer resistance to cope this problem is by preventing the successful reforestation program as shown on some picture bellow.
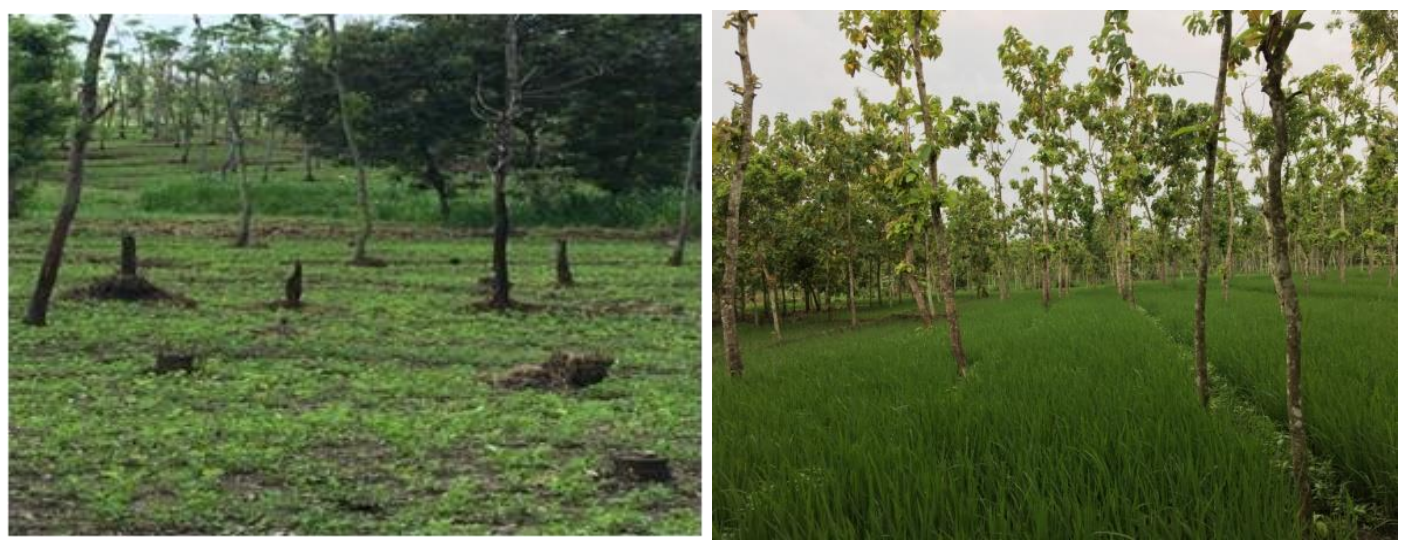

Picture 2. Peanut agriculture in forest area and some burnt dead trees (left) and Small lines for teak tree and less tree canopy in forest area for rice agriculture (right)

Rice agriculture in Ngawi regency is affected with green revolution through rice self sufficiency policy. Farmer in this area becomes more familiar with chemical fertilizer, pesticides and herbicides to increase their productivity. It can be seen that Ngawi regency during 20002010 has productivity above East Java Province and Indonesia productivity, but decreased in 


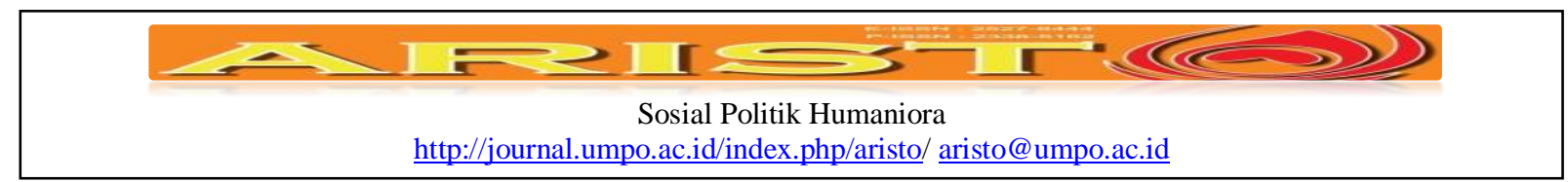

2011 up to 2014. The decreasing was because the brown plant hopper annual attack. Intensive rice farming is prone to pest outbreak risk, since 2010, the infestation of brown plant hopper (BPH), Nilaparvata lugens happen in Ngawi rice field and then in 2011 severely damaged 18,448 hectare rice field (East Java Province Board Planning Agency).

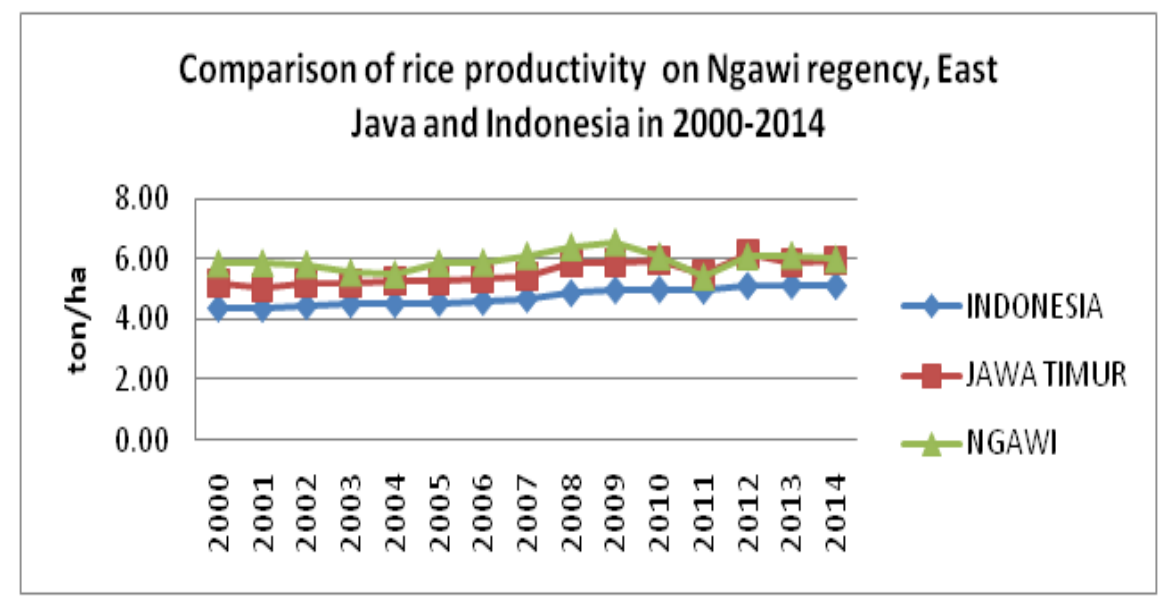

Source: Ngawi and Indonesia Statistic data

Figure 6. Rice productivity in Ngawi regency 2000-2014

Some reasons for farmer to cultivate rice in dry season are the higher productivity and price. In dry season when the sun ray intensified without many cloudy days, rice plant can grow optimally and produce less moisture content grain which increases the grain price. According to interviewed farmer, rice price in dry season could reach 3,700 idr which is higher than in rainy season which only range from 3,000-3,500 idr.

The success of dry season rice agriculture is on irrigation water availability. Whilst existing irrigation systems only support rainy season cultivation, irrigation farmer start copied well irrigation from irrigation agency to fulfill their water need. Some other factor that promoted the use of well irrigation are:

a) Relatively cheap water pump price

b) High rice harvest yield and price in dry season

c) Prepaid electricity policy that released in 2010 is open the access for electricity in rice field and enable deeper ground water extraction by using submersible pump. 

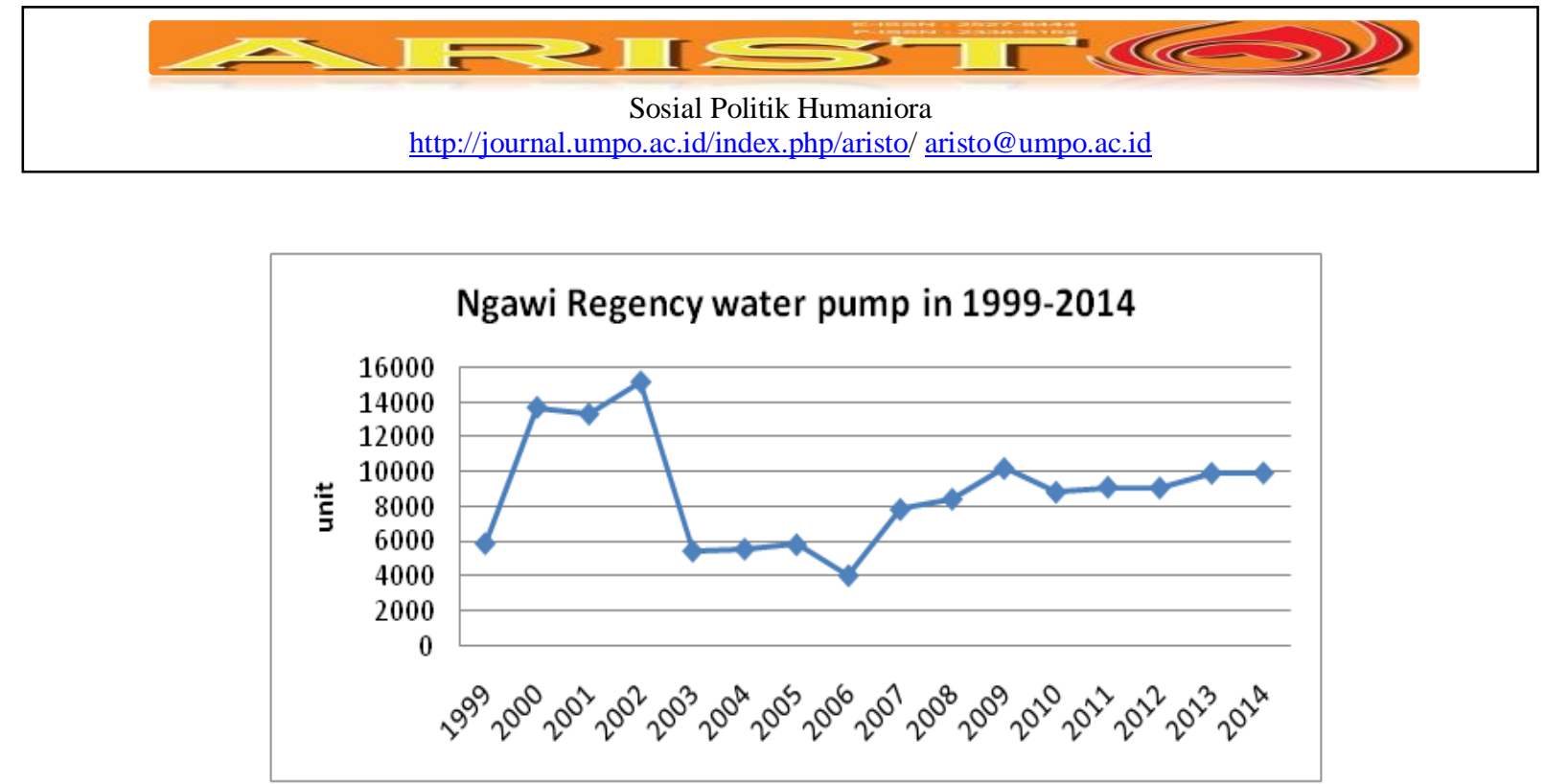

Source: Ngawi statistic data compiled by author

Figure 7 Trend of pump number in Ngawi Regency area in 1999-2014

The number of water pump indicates the rapid ground water extraction in this area. Although decreased in number since 2002, but through the fieldwork observation, the wells become deeper up to 100 meters depth. According to Dani (2011), the decreasing water table was happen 2011 in many areas in Ngawi regency such as in Paron sub district for 3-5 m, in Geneng Sub district for 6-8 meter, and Gerih sub district for 7- 14 meter. In Begal rice field area, there are 7 well that ranged from $30-100 \mathrm{~m}$ and one of it is artesian well. If assumed that the condition of rice field that irrigated by Margo spring water (16.5 ha with 7 well) is the same with Ngiyom irrigation area, it predicted that more than 600 well established in this area or even more. The resulting situation is that ground water is almost impossible to extract with manual effort (dug well).
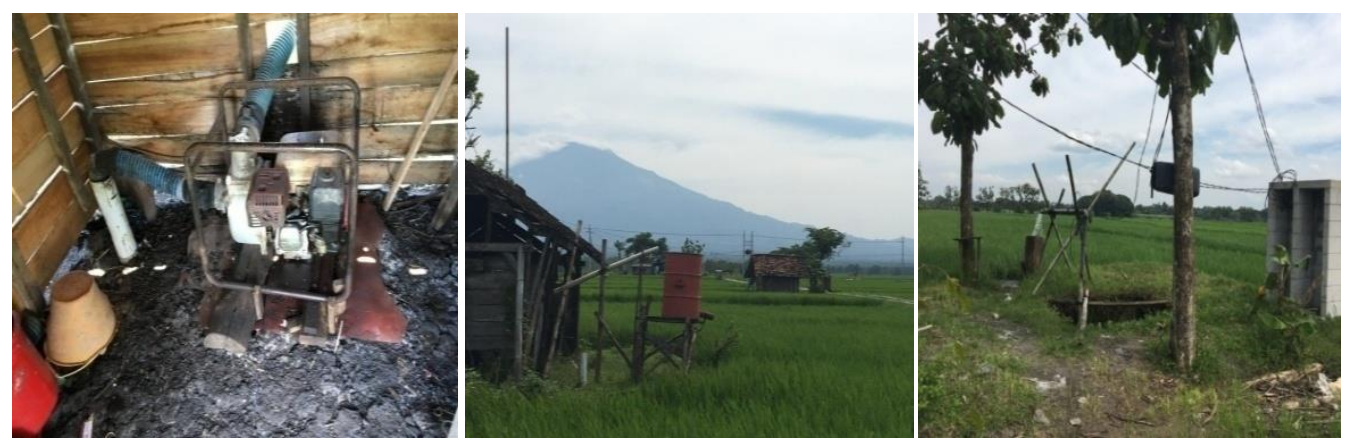

Picture 3. Diesel pump in 30m depth well, many hut in rice field for well equipment, and deep well using electric submersible pump in rice field area 


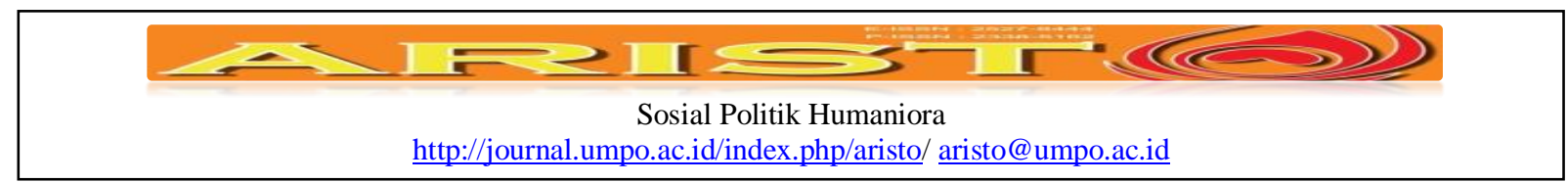

Furthermore, not every well drill is successful. There are some cases of failed drilling from failed to get the water into gas explosion. Ngawi regency located near inland oil drilling in Cepu oil blocks which only 60.5 kilometres away. The two case of well drill explosion was happen in Kedunggalar and Widodaren sub district where Begal forest located. The drill well explosion risk is faced by farmer in this area and worsen with the loose law enforcement of ground water utilization in Indonesia Government Law 43/2008 and it derived Law
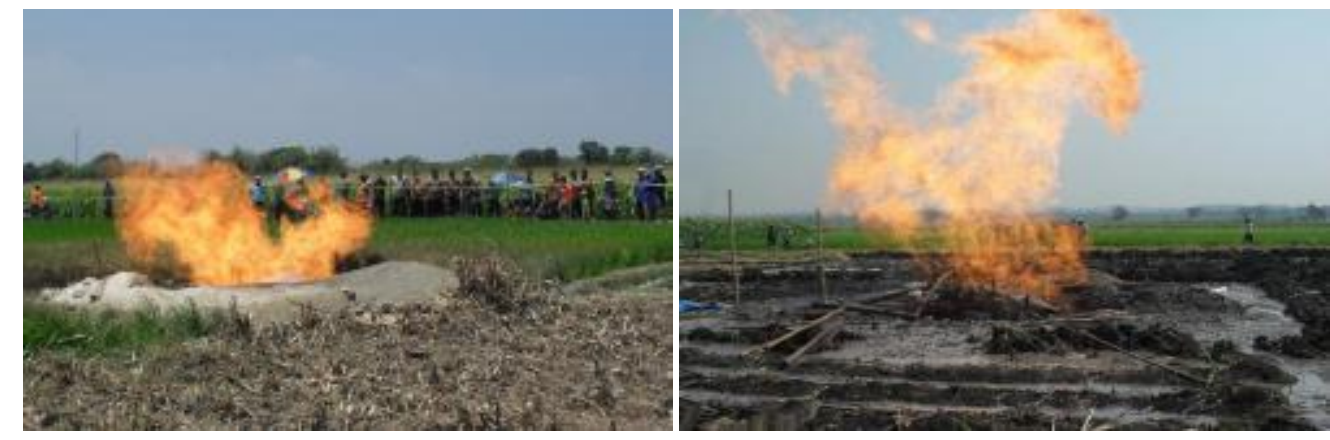

Source: Surya tribun news

Picture 4. Well drilling explosion in Widodaren Sub district 2013 and 2014 From the interview, some factor that affecting the water contestation problem in this area are;

\section{Unequal resources benefit distribution}

\section{Unequal spring water benefit distribution between forest and irrigation farmer}

Economic gap among forest farmer which is landless and irrigation rice farmer land own become justification for forest farmer to utilize spring water. Margo and Ngiyom spring are located in Begal production forest which the main access is from Sekarputih village. But the water from these two spring water was utilized for rice field irrigation in another village and sub district. Based on the interview, landless farmer in Sekarputih felt that the economic advantages from spring water utilization only benefit other village farmers and it proved by the monthly average income gap of forest farmers which only achieved 142.916 rupiah/ month whilst irrigation farmers 2.296.875 rupiah/month and housing condition where forest farmers mostly live in wooden house without paved floor while irrigation farmers mostly live in permanent concrete house. After loose forest governance, they start doing rice agriculture in river side and near spring area.

Water utilization that monopolized by forest farmer is lead to water contestation in this area. After tried to confront with forest farmer about water utilization and mediated with city 


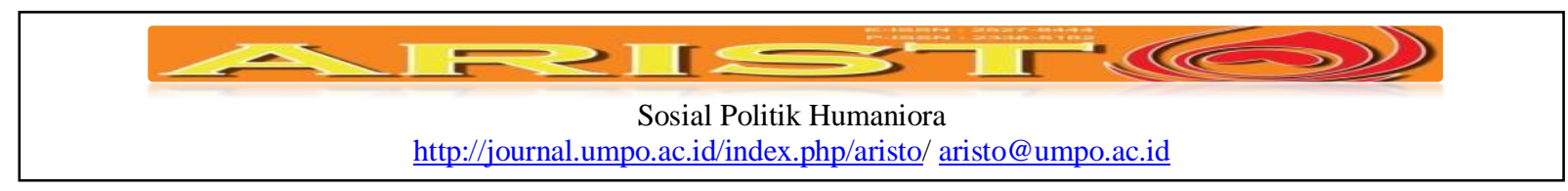

council but not yet resolved, irrigation farmer start to find surplice water from ground water extraction. The intensive rice agriculture is causing well irrigation become more common for rice field irrigation which creates rapid ground water extraction in this area. Moreover, high fertilizer use is dried up the soil which makes water demand increase (Shiva, 1993).

\section{Unequal forest resource benefit distribution between forest farmer and Indonesian Forest Enterprises}

Long history of state production forest governance was affecting local people near forest area. According to Peluso (1993), from the beginning of state production forest establishment, forester and government officer believed that excluding local people from forest utilization will reduce their claim over forest product. Repressive way often used to limit local people access to forest. Local people were seen as cheap labor provider for production forest work.

After Indonesia independence, the state forest authority was under forestry ministry and later delegated to Indonesian Forest Enterprises to fund the Indonesia development. In 2001, Indonesian Forest Enterprises was under the authority of State Enterprise Ministry, which cleared the production forest profit oriented purpose. Less sustainable log harvest is also caused by timber theft in forest area to supply furniture industry material.

Timber theft actors always associated to local people, which create social problem between forest authority and local people. Most of forest farmer respondent felt offended and afraid to answer about the Begal forest condition in mass deforestation or if asked about their relation with forest authority. It might be caused by stereotyping by forest authority to local people near forest area. Based on researches that conducted by NGOs Arupa and LBH Semarang, during 1998 - 2011 Indonesian Forest Enterprises had 108 conflict cases with villagers around forests for timber theft or forest destruction in Java Island, 34 of them were shot or abused by Forest security officer and 74 others injured. Types of violence committed by forest officials ranged from terror, torture, up to killing citizens and criminalize people who accused as timber theft.

Usufruct forest product, such as tree branch for fire wood as well as agriculture in forest area which done through taungya agroforestry system,. was given to local people to reduce their claim over forest product. taungya was initiated by Ducth forester in late $19^{\text {th }}$ century (Peluso, 1993) and continued after independence up to nowadays despite of its failure in improving local 


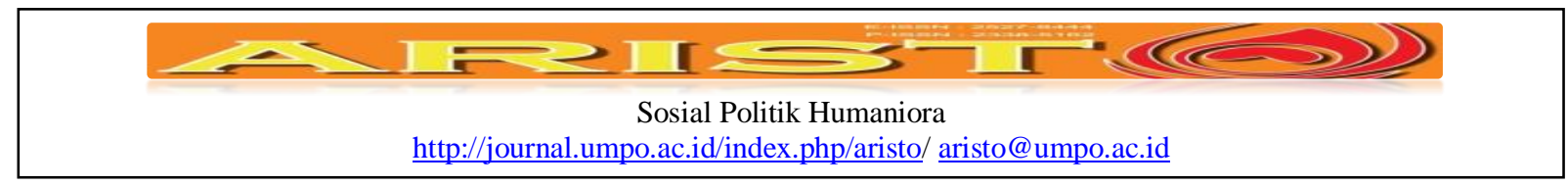

people economic condition. After 2000, Community based forestry program also adopt, modify and legalized this agro-forestry mechanism to overcome post mass deforestation problem. Unavailable continuous agro forestry area because mass reforestation, has made forest farmer overcoming the problem by resisting the reforestation success and do rice agriculture in spring and riverside in forest area which causing water contestation problem. . In Begal forest area, this program regulated in 2004 with the establishment of Community Base Forestry named "Jati Lestari but its partnership contract agreement content was only decided by Forest Company. Some benefit that achieved by CBFM from log thinning in forest area according to the partnership contract are will be achieved in 10 year, 15 year, 25 year, and 40 year tree age with forest authority decided term and condition.

Unequal partnership between local people (Forest Farmer) and forest authority (Indonesian Forest Enterprises) is hindering the success of forest co-management program through community base forestry. Furthermore, it creates lack of choice to local people near forest area to sustain their source of income from forest area utilization. It was not so easy for poor rural people to define a choice, not only because their assets are limited, but also poor people often experience and feel of being isolated, left out, looked down upon, alienated, and ignored by the mainstream socio-cultural and political process (Narayan, et al,2000, p 133).

\section{High dependency on intensive agriculture sector}

Limited job opportunity due to low education level and limited available formal job vacancies in this area make almost all local people in Sekarputih and Begal village work in agriculture sector. Green revolution policy has make farmer in this area becomes familiar with chemical fertilizer, pesticides and herbicides to increase their productivity. Benefit from cash crop practices encourage farmer to produce more in order to gain more and led irrigation farmer to shift their rice cultivation trend into intensive rice agriculture 3 times per year) which cause increased rice agriculture water need and forest farmer start doing rice agriculture in river side and near spring area.

The increasing water demand was not fulfilled by the irrigation system which designated for 2 times rice cultivation per year (in the first and third cultivation period). The convenience of using well irrigation from irrigation agency deep well, water contestation problem and the changing in rice cultivation make farmer started to make their own well. Unfortunately, Intensive 


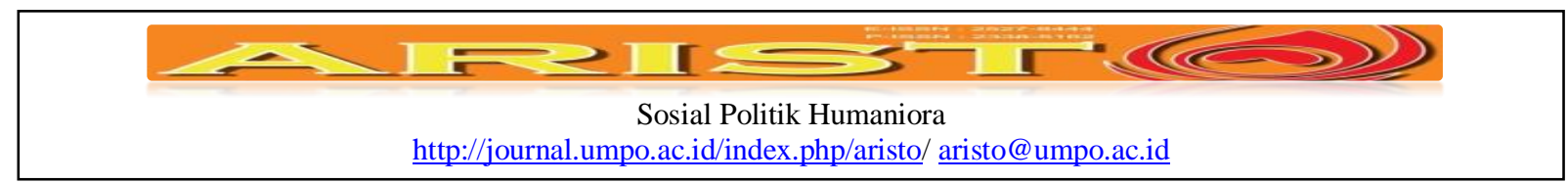

rice agriculture productivity in Ngawi regency was decreased in 2011 up to 2014 because the brown plant hopper infestation. Increasing production cost for irrigation water and pest infestation make rice farmer livelihood at risk and make them more dependent on rice agriculture.

\section{Loose forest governance}

Based on conducted interview, freedom of speech and human right recognition which intensified in reformation era has deprived Forest Company officer to secure forest in strict way. Previous failure of social forestry program implementation is resulting constant conflict of Indonesian Forest Enterprises and Local people near forest area over the access to forest resource for livelihood. 1998-2000 mass deforestation can be seen as the peak of conflict in forest governance by Indonesian Forest Enterprises. In overcoming the problem, community base forestry program was regulate in 2001 by establish legal forestry community in village level. However, this program done without equal partnership because all articles in partnership contract were made by Forest Company and less benefited local people which resulting on forest farmer resistance and un-improved local people economic condition (short agroforestry time and long period of achieving shared benefit).

Due to supporting National food security program for state own Enterprises, some forest area has been allocated for agro-forestry by local people farmer. Moreover, less forest officer number in this area (only 5 officer) and highlighted by many NGO for occupy 2.4 million hectare production forest in Java Island and high number of poverty near forest area make Indonesian forest enterprise loosen their governance in this area.

\section{No law enforcement on ground water extraction}

In Indonesia the law that regulated water resources management and utilization is Government Law 43/2008 about water resources. This law was already adopted by Ngawi Local Government with Ngawi regency Regional Law no. 23/2012 on water conservation and Ground Water management. According to article 34 (3), this law allowed ground water extraction for agriculture use without applying formal permission if followed several condition such as;

a. The discharge of groundwater does not bring problem to local community daily water needs; 


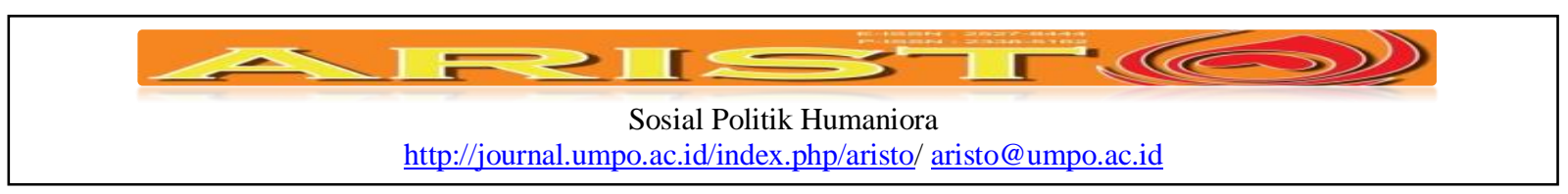

b. Wells should located in agricultural areas away from the settlements; and

c. Use no more than 2 (two) litters per second per hectare, if surface water is not sufficient. This article usually used by local regency officer to allow the ground water extraction for agriculture water need. However, loose regulation has resulting on addition of agriculture well number and utilization of submersible pump which have high suction capacity (for 100m depth, maximum flow rate is 15 liter per second, which lowering the water table (deepen the well up to $100 \mathrm{~m}$ ). although already impacting the water table but up to now there is not any act from Ngawi local Regency to limit the ground water extraction. Not enough socialization of the ground water law and information on Ngawi regency hydrogeology condition which lies in Ponorogo-Ngawi ground water basin are made local people unaware of potential risk of excessive ground water extraction.

The effort to socialize and enforce the Government Law no. 43/2008 on water conservation and Ground Water management should be done immediately to avoid further environmental risk. According to my observation, the trend of well irrigation is also happening in other region of east java and central java province as cheap electricity power and modify water pump with high suction power is easily available.

\section{Conclusion}

In summary, government policy on rice agriculture and forestry sector was indirectly affecting the water contestation problem in this area. From forest resource governance side, changes in forest area utilization after 2000 mass deforestation in Begal forest area into rice field in spring and river area, un-success community base forestry management program make forest farmer utilize spring water for rice agriculture in forest area (the water previously utilize for irrigation farmer), loose forest governance because of internal and external pressure on Indonesia forest Enterprises are some factor that causing water contestation between forest farmers and irrigation farmers in this area.

From agriculture governance, government policy on rice self sufficiency program (on Suharto's era) which weighed triggered the change in rice planting cycle into 3 times per year which resulting increasing water demand which cannot be fulfilled. As the water resources monopolize by forest farmer, the water contestation problem was remain unresolved, and then dam damages are some cause of water problem. Well irrigation is utilized by irrigation farmer as 


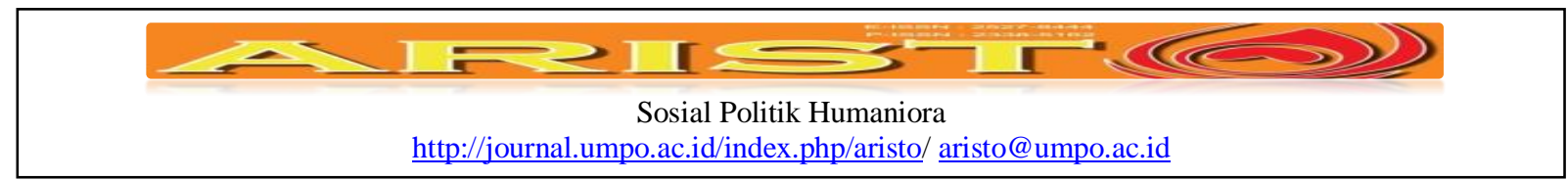

self-solution for fulfilling agriculture water need, and then well number is increase and more deep overtime in almost all Ngawi area. Decreasing water table, well drilling failure and increasing groundwater extraction cost are some risk that faced by irrigation farmer. Located in cross province groundwater basin make depletion water table in this area would affect many other region.

In conclusion, Combination of; agriculture and forestry policy management side effect are causing economic gap (between forest vs. irrigation farmers) and led to more intensive rice agriculture; and loose forest and agriculture governance which allow rice agriculture in forest area and deep well irrigation in rice field were causing water contestation problem in this area and would led into water scarcity problem in future. This condition was in line with SES framework which stated that the resources user actions toward resources utilization are affected by the resources governance policy. 


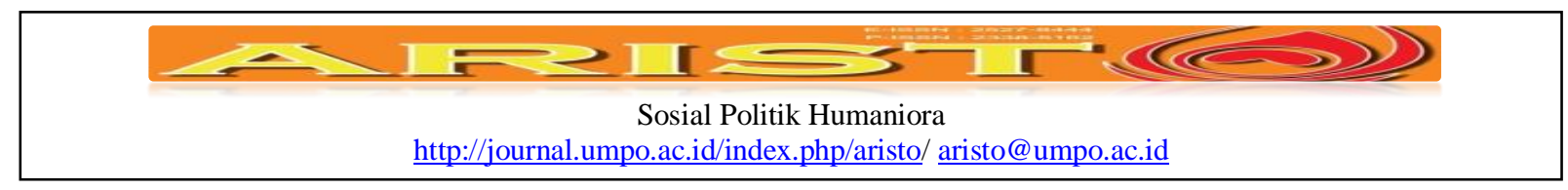

\section{References}

Anderies, J. M., M. A. Janssen, and E. Ostrom. 2004. A framework to analyze the robustness of social-ecological systems from an institutional perspective. Ecology and Society 9(1): 18. [online] URL: http://www.ecologyandsociety.org/vol9/iss1/art18/

Danni, Y. Kurniawan, 2011, Pemanfaatan sumber daya air bagi kegiatan budidaya di daerah Pengaliran sungai (dps) ketonggo kabupaten Ngawi, unpublished master tesis, Magister perencanaan kota dan Daerah, UGM, Indonesia

Ostrom, E , .(1990).Governing the Commons: The Evolution of Institutions for Collective Action. Cambridge: Cambridge University Press.

Peluso, L.N., 1993, Tradition of Forest control in Java: Implication for social forestry and sustainability, global ecology and biogeography letters, vol. 3 no. 4/6, The political ecology of southeast Asian forest : transdisciplinary discourses, Wiley, pp. 138-157

Manning, Chris, 1987, Public Policy, Rice Production, and Income Distribution: Review of Indonesia Rice Self- Sufficiency Program,South east asian journalof social science Vol 15. No. 1 Social AND Political Change In Contemporary Indonesia, Brill.

Narayan, Deepa, Patel, R., and Schafft, 2000, Can Anyone Hear Us?: Voices of the Poor, World Bank Publication.

Peluso, Nancy Lee. 2006, Hutan Kaya Rakyat Melarat: penguasaan sumberdaya dan perlawanan di Jawa. Konphalindo, Jakarta.

Santoso, Hari. 2004. Perlawanan di Simpang Jalan: Konteks Hutan di Desa-Desa Sekitar Hutan Jawa. Damar Press. Yogyakarta.

Suprapto, E., A., B., 2013, Hutan Jawa : kontestasi dan kolaborasi, Biro Penerbitan ARUPA, Yogyakarta , ISBN 978-979-96513-6-5.

Shiva, Vandana, 1993, The Violence of the green revolution; third world agriculture, ecology and politic, Zen book Ltd, London \& New York.

Walker, B., Gunderson, L., Kinzig, A., Folke, C., Carpenter, S., and Schultz, L.(2006).A handful of heuristics and some propositions for understanding resilience in social-ecological systems. Ecol. Soc. 11, 13. 


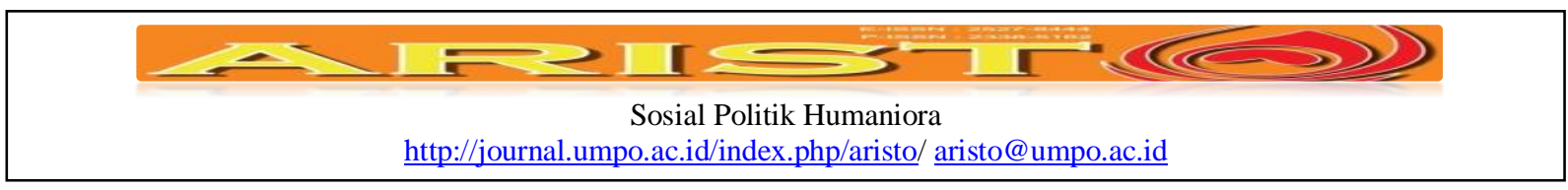

Zips,W. and Weilenmann M., 2011, The Governance of Legal Pluralism: Empirical Studies from Africa and Beyond, LIT Verlag Münster, 304p.

https://perhutaniunit3.wordpress.com/2013/09/26/sejarah-perum-perhutani/

http://www.mongabay.co.id/2013/01/28/pegelolaan-hutan-di-jawa-oleh-perhutani-dinilai-gagalsejahterakan-masyarakat/

http://bumn.go.id/perhutani/halaman/159

Pengelolaan Hutan Bersama Masyarakat (PHBM) 2014 by Perum Perhutani.

Government data:

1. Ngawi dalam Angka 203, 2004, 2007, 2010, 2011, 2013, 2014

2. Statistik kecamatan Kedunggalar 2015

3. Statistic Kecamatan Widodaren 2015

4. Profil desa Sekarputih 2016

5. Perhutani report 2016

6. https://www.bps.go.id/linkTable Dinamis/view/id/864 Produksi padi Indonesia 1993-2013

7. Statistik Perhutani tahun 2009-2013 